\title{
Correlation of Sfil macrorestriction endonuclease fingerprint analysis of Candida parapsilosis isolates with source of isolation
}

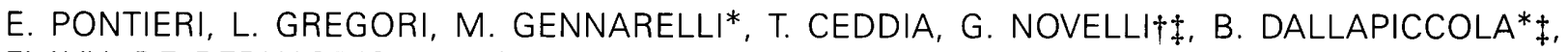 \\ FLAVIA DE BERNARDIS $\S$ and G. CARRUBA
}

Department of Experimental Medicine, University of LAquila, LAquila, *Department of Public Health and Cell Biology, Tor Vergata University of Rome, †Chair of Human Genetics, Catholic University of Rome, $\ddagger$ Chair of Genetics, University of Urbino and §Laboratory of Bacteriology and Medical Mycology, Istituto Superiore di Sanità, Rome, Italy

Sfi I macrorestriction digests from whole chromosome DNA preparations of 46 isolates of Candida parapsilosis from vaginal (20 isolates), blood (23 isolates) and soil (three isolates) sources were examined by CHEF-MAPPER pulsed-field electrophoresis. The isolates were grouped into nine macrorestriction endonuclease fingerprint (MEF) classes according to the number or size of the macrorestriction fragments, or both. The electrophoretic karyotype (EK) was also examined and found to contain 18 karyotypic classes (named A-R). A comparison between $S f i$ I MEF and EK demonstrated that the former correlated much better than the latter with the source of $C$. parapsilosis isolates. Five $S f i$ I classes (I-V) contained only vaginal isolates (or vaginal and three soil isolates, class I), and the blood isolates were distributed between four classes (VI-IX). This relationship was less evident with the EK classes as several of these were composed of both vaginal and blood isolates $(B, G, L$ and $M)$. The three soil isolates were in class $A$ which also included one vaginal isolate. We conclude that $S f i I$ macrorestriction endonuclease patterns seem to be useful in discriminating among $C$. parapsilosis isolates, with apparent association with source of isolation.

\section{Introduction}

Candida parapsilosis has become increasingly important as a prevalent yeast species in fungaemic episodes [1-3] affecting neutropenic and severely debilitated patients receiving parenteral nutrition $[4,5]$. Recent evidence also points to a role for $C$. parapsilosis in human vaginitis [6]. Vaginal isolates of this species produce one or more aspartylproteinase enzymes in vitro and in vivo. It has been suggested that these are involved in the pathogenesis of vulvovaginitis [6]. Experimental pathogenicity for cyclophosphamide-immunodepressed mice demonstrated the ability of vaginal and blood isolates, but not soil isolates, to cause systemic infections in the mouse $[7,8]$. The above-mentioned differences suggest that different biotypes exist among $C$. parapsilosis isolates, whose identification could be important for pathogenicity, diagnostic and epidemiological studies.

In $C$. albicans, molecular approaches for epidemio-

Received 12 Oct. 1995; revised version accepted 19 Jan. 1996.

Corresponding author: Professor G. Carruba. logical studies based on DNA analysis have been extensively developed. Restriction fragment length polymorphism (RFLP) analysis [9] particularly concerning mitochondrial [10] and ribosomal DNA [11], and analysis of various repetitive, dispersed genomic DNA sequences have been reported [12-14]. Electrophoretic karyotype analysis (EKA) techniques have also been developed and applied [15-17] by means of several pulsed-field gel electrophoresis (PFGE) systems [18-20]. All these techniques demonstrated the heterogeneity and genetic diversity of $C$. albicans isolates, but they did not demonstrate any correlation with isolation source or pathogenicity. In C. albicans, DNA translocations have been suggested to be involved in chromosome-length polymorphism (CLP) [21]. In the absence of a sexual cycle, these translocations are hypothesised to be a potential source of genetic variability.

Although considerably less genetic information is available concerning $C$. parapsilosis isolates, available data point to genomic intraspecies diversity. In a previous study, whole-chromosome DNA preparations of 16 isolates of $C$. parapsilosis from different sources (soil, vaginitis and candidaemia) were examined [22]. 
The patterns of bands obtained after digestion with the restriction endonucleases Eco RI, Hind III, Bam HI, $B g l \mathrm{II}, H p a \mathrm{II}, P v u \mathrm{II}, H i n \mathrm{fI}$ did not discriminate among isolates. In contrast, electrophoretic karyotypes generated by CHEF showed remarkable heterogeneity, resulting in the definition of seven karyotypic classes on the basis of the number or size of chromosomes, or both [22], in accord with the findings of other authors $[18,23,24]$. Clinical isolates were found in separate karyotypic classes.

In the present study, Sfi I and Not I (rare cut-site endonucleases) were tested as an approach to DNA fingerprinting of human isolates of $C$. parapsilosis (vaginal and blood) and from soil.

\section{Materials and methods}

\section{Yeasts}

Forty-six isolates of $C$. parapsilosis obtained from soil or from vaginitis or candidemic patients were analysed $[8,23]$. All isolates were identified according to established laboratory procedures as follows: morphological analysis on corn meal agar, germ-tube formation in serum, carbon source assimilation (API) profile analysis with the ID 32C yeast identification system (bioMérieux, SA), and agglutination tests with antiCandida sera (Candida check Kit, Iatron Laboratories Inc., Tokyo, Japan). Vaginal isolates were from patients with vaginitis or from asymptomatic carriers.

\section{Sample preparation}

Several colonies from each $C$. parapsilosis isolate were grown separately to stationary phase (as assessed by measurements of optical density of cultures) in $5 \mathrm{ml}$ of YPD medium (dextrose $2 \% \mathrm{w} / \mathrm{v}$, Bacto-peptone $2 \% \mathrm{w} / \mathrm{v}$, yeast extract $1 \% \mathrm{w} / \mathrm{v}$, Difco) at $30^{\circ} \mathrm{C}$ in $15 \mathrm{ml}$ Falcon 2099 tubes in a rotatory shaker (Gallenkamp) set at $200 \mathrm{rpm}$. The cells (in pure yeast form) were harvested and washed in solution A (1.2 M D-sorbitol and $20 \mathrm{mM}$ EDTA, pH 8). The pellet was resuspended at a concentration of $10^{9}$ cells $/ \mathrm{ml}$ in solution B (solution A with the addition of $20 \mathrm{mM} \beta$-mercaptoethanol) and incubated at $37^{\circ} \mathrm{C}$ for $10-15 \mathrm{~min}$. Then low-meltingpoint agarose (BioRad) $1.5 \% \mathrm{w} / \mathrm{v}$, dissolved at $65^{\circ} \mathrm{C}$ in solution $\mathrm{A}$, was added at a final concentration of $0.75 \% \mathrm{w} / \mathrm{v}$ and samples were solidified at $4^{\circ} \mathrm{C}$. Then, the agarose blocks were overlaid for $2 \mathrm{~h}$ at $37^{\circ} \mathrm{C}$ with solution C (1.2 M D-sorbitol, $20 \mathrm{mM}$ EDTA, $10 \mathrm{mM}$ Tris- $\mathrm{HCl}, \mathrm{pH} 7.5$, and Lyticase, Sigma, $0.1 \mathrm{mg}$ ) for spheroplast formation. After discarding solution $\mathrm{C}$, the agarose blocks were lysed in solution D (sodium dodecyl sulphate, $1 \% \mathrm{w} / \mathrm{v} 100 \mathrm{mM}$ EDTA and $10 \mathrm{mM}$ Tris- $\mathrm{HCl}, \mathrm{pH} 7.5)$ at $37^{\circ} \mathrm{C}$ overnight. Finally, solution D was replaced by solution $\mathrm{E}$ (N-lauroylsarcosine $1 \% \mathrm{w} / \mathrm{v}$, $100 \mathrm{mM}$ EDTA and $10 \mathrm{mM}$ Tris- $\mathrm{HCl}, \mathrm{pH} 7.5$ ) and the samples were stored at $4^{\circ} \mathrm{C}$.

\section{Karyotype analysis}

Chromosome-sized bands of $C$. parapsilosis were separated by the CHEF-MAPPER system (BioRad) under either of two conditions as follows. Condition A: $72 \mathrm{~h}$ with a pulse-time from $60 \mathrm{~s}$ to $500 \mathrm{~s}$ at $120 \mathrm{~V}$ constant voltage, in agarose $1 \% \mathrm{w} / \mathrm{v}$ gel. Electrophoresis buffer was $0.5 \times \mathrm{TBE} 45 \mathrm{mM}$ Tris base, $45 \mathrm{mM}$ boric acid and $1 \mathrm{mM}$ EDTA mantained at a constant temperature of $14^{\circ} \mathrm{C}$. Condition $\mathrm{B}: 72 \mathrm{~h}$ with a pulsetime from $60 \mathrm{~s}$ to $300 \mathrm{~s}$ and $150 \mathrm{~V}$ constant voltage. Agarose gel concentration, electrophoresis buffer and its working temperature were the same as for condition A. After electrophoresis, gels were stained in a solution containing ethidium bromide $0.5 \mu \mathrm{g} / \mathrm{ml}$ for $30 \mathrm{~min}$, destained in distilled water for $1 \mathrm{~h}$ and photographed with Polaroid 667 film (Polaroid Corporation).

\section{Sfi I and Not I digestion}

Agarose blocks were incubated overnight in $0.5 \mathrm{M}$ EDTA, $\mathrm{pH} \mathrm{8,} \mathrm{at} \mathrm{room} \mathrm{temperature,} \mathrm{then} \mathrm{washed} \mathrm{for}$ $30 \mathrm{~min}$ with sterile distilled water three or four times. Then the samples were digested with $S f i \mathrm{I}$ or Not I restriction endonucleases (Boehringer Mannheim $\mathrm{GmbH}$ ) under the following conditions: one agarose block ( $82 \mu \mathrm{l}$ volume), was placed in a $1.5-\mathrm{ml}$ Eppendorf tube containing $20 \mu \mathrm{l}$ of $S f i \mathrm{I}$ or Not I $10 \times$ digestion buffer and 40-60 units of the appropriate enzyme and adjusted to a final volume of $200 \mu \mathrm{l}$ with sterile distilled water. Digestion was carried out at $50^{\circ} \mathrm{C}$ for $S f i \mathrm{I}$ and $37^{\circ} \mathrm{C}$ for Not $\mathrm{I}$ for $6 \mathrm{~h} \mathrm{[25].}$

\section{Sfi I and Not I digestion pattern analysis by PFGE}

The BioRad CHEF-MAPPER system [20] was used to analyse $S f i$ I- or Not I-generated DNA fragments by the following parameters: two electrophoresis periods of $24 \mathrm{~h}$, with switch times of $90 \mathrm{~s}$ and $120 \mathrm{~s}$, respectively, at $150 \mathrm{~V}$ constant voltage in agarose gel $1 \% \mathrm{w} / \mathrm{v}$. All the gels were electrophoresed in $0.5 \times$ TBE buffer (45 mM Tris base, $45 \mathrm{~mm}$ boric acid and $1 \mathrm{mM}$ EDTA) at a constant temperature of $14^{\circ} \mathrm{C}$. Gels were stained in a solution of ethidium bromide $0.5 \mu \mathrm{g} / \mathrm{ml}$ for $30 \mathrm{~min}$ after electrophoresis, destained in distilled water for $1 \mathrm{~h}$ and photographed with Polaroid 667 film (Polaroid Corporation).

\section{Results}

\section{Electrophoretic karyotype}

The electrophoretic karyotypes (EK) of the 46 isolates of $C$. parapsilosis were examined. Several electrophoretic runs from different preparations of agarose plugs for each isolate were compared with the CHEFMAPPER system. Electrophoresis was performed under the two sets of conditions described in Materials and methods, because of the wide range of sizes of 
chromosomal bands. In fact, high- and low-range chromosomal bands were hardly separated by only one set of electrophoretic conditions. As found previously by the TAFE pulsed-field electrophoresis technique [26], the five chromosomal bands which define the high range $(3-1.5 \mathrm{Mb})$ of chromosome-sized DNA bands were similar in size in all isolates of $C$. parapsilosis tested. By use of the CHEF-MAPPER technique these data have been confirmed for all isolates except five belonging to classes $F, G, K$ and $R$ (Fig. 1a). Marked isolate-dependent variations were found for smaller sized chromosomal bands (in the range $1.45-0.65 \mathrm{Mb})$. These variations allowed the grouping of isolates into 18 classes (Figs. $1 \mathrm{~b}$ and 2). A complete association was not found between any particular karyotype class and source of isolation. Classes B, G, L and M all contained vaginal and blood isolates.

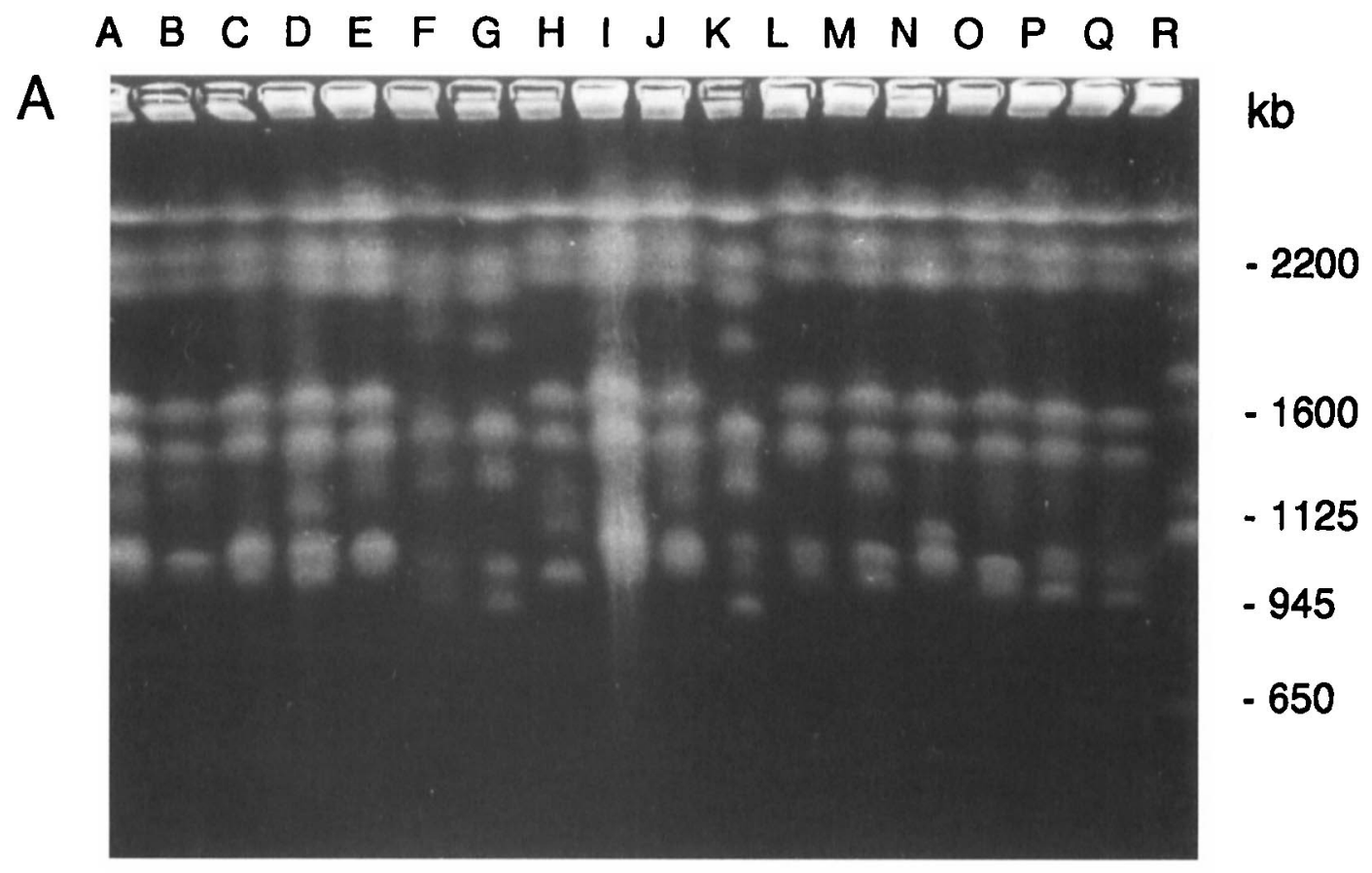

A B C DEF G H I JKL M NOPQR

B

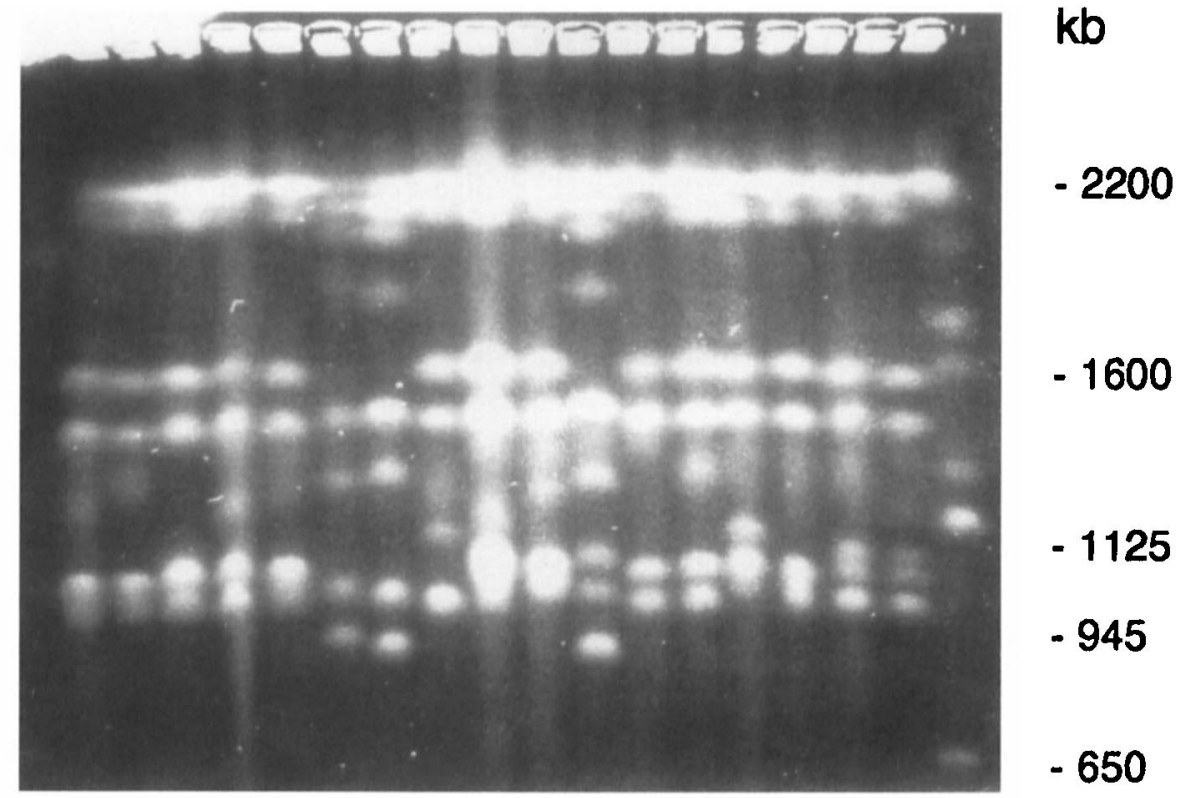

Fig. 1. Electrophoretic karyotype patterns (A and B) of the 46 C. parapsilosis isolates. The karyotype of only one isolate is shown for each class. Sizes $(\mathrm{kb})$ of the most important chromosomal bands are indicated on the right. 


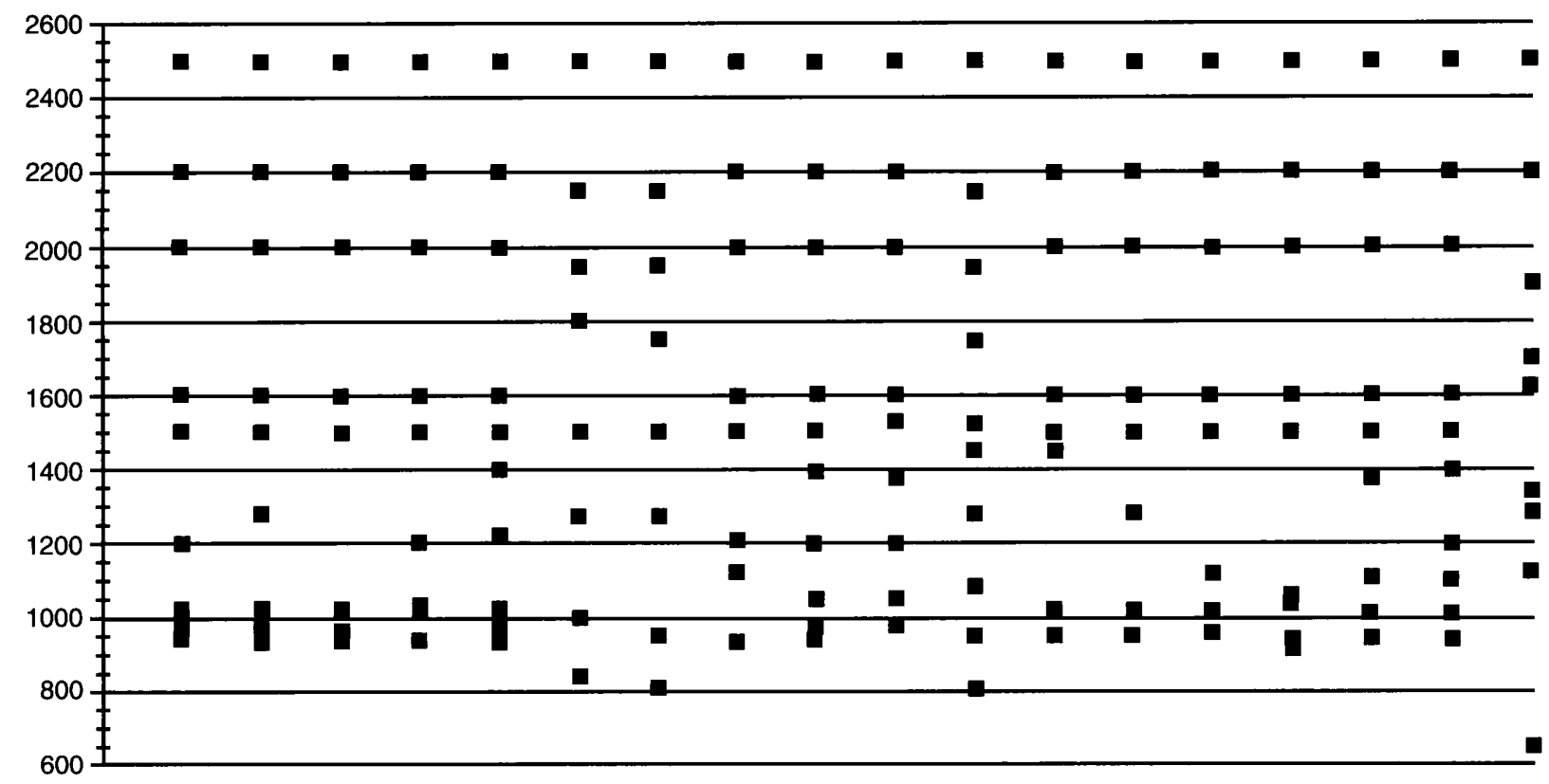

Fig. 2. Putative sizes $(\mathrm{kb})$ of chromosomal bands obtained by karyotyping of the 46 C. parapsilosis isolates grouped into 18 classes (A-R).

\section{Sfi I and Not I digestion patterns}

As found in preliminary experiments, Not I digestion pattern analysis did not give discriminatory results, as all isolates tested (except HEM18) showed an identical macrorestriction endonuclease fingerprint (MEF) (data not shown). On the contrary, Sfi I digestion proved to be a useful discriminator. Forty-two of the 46 isolates studied showed four similar bands in the range 2$1.6 \mathrm{Mb}$ (in Fig. 3 they are compressed into a unique band, the first, depending on the electrophoretic conditions) accompanied by a number of restriction fragments below $450 \mathrm{~kb}$ virtually identical in all strains except the isolates in class V. However, remarkable polymorphisms were seen in the region $1.2-0.75 \mathrm{Mb}$. These polymorphisms consisted of four bands with markedly different sizes among isolates, thus allowing grouping of the 42 isolates into six classes (designated as I, II, IV, V, VI and VII) (Fig. 4). Two classes (VI and VII) included 21 blood isolates and none from other sources. Classes II, IV and V contained only vaginal isolates (eight). Finally, class I included 10 vaginal and three soil isolates. Only four isolates could not be assigned to any major class as above. They showed a very peculiar $S f i$ I digestion pattern, characterised by $c$. 25-28 restriction fragments, spread all over the size range of mol. wt standards. They were grouped in class III (two vaginal isolates) and in classes VIII and IX (one blood isolate each).

\section{Discussion}

Previous studies by several groups of workers have shown that only the determination of the electrophoretic karyotype has a discriminatory power for biotyping C. parapsilosis isolates $[18,22]$. DNA digestion with several restriction endonucleases (such as Eco RI, Hind III, etc.) did not generate useful biotyping patterns $[22,27]$; each enzyme tested produced, for all isolates examined, an identical, highly reproducible digestion pattern. Lott et al. [23] used RAPD (randomly amplified polymorphic DNA) and TAFE (transverse alternating field gel electrophoresis) pulsed-field techniques to biotype both clinical (only blood) and nonclinical (stock collection) isolates of $C$. parapsilosis. They found genomic heterogeneity among their isolates, and found them characterised by phenotypic switching generating variability in electrophoretic karyotype. Branchini et al. [24] analysed blood and catheter isolates of $C$. parapsilosis by the $\mathrm{CHEF}$ pulsed-field technique and the digestion of wholechromosomes with Bss HII, a rare cut-site restriction endonuclease, together with slime production. This digestion generated polymorphisms, and the authors claimed that MEF was useful for biotyping $C$. parapsilosis. All these studies showed remarkable heterogeneity among isolates, confirming the widely accepted view about the biotype diversity of $C$. parapsilosis isolates $[8,18,22]$.

In the present study 46 C. parapsilosis isolates from two clinical sources (vaginal and blood) and from soil were analysed, including isolates endowed with highly diverse morphotype and virulence characteristics [8]. To biotype these isolates, a comparative analysis of the electrophoretic karyotype and $S f i \mathrm{I}$ digestion pattern was made. As shown by several authors $[18,22-24]$ the determination of the electrophoretic karyotype provided an efficient, highly discriminatory biotyping system but had the disadvantage that, as shown here, most isolates had a unique pattern, unrelated to the source of isolation or pathogenicity [8]. In fact eight karyotypic classes had only one 


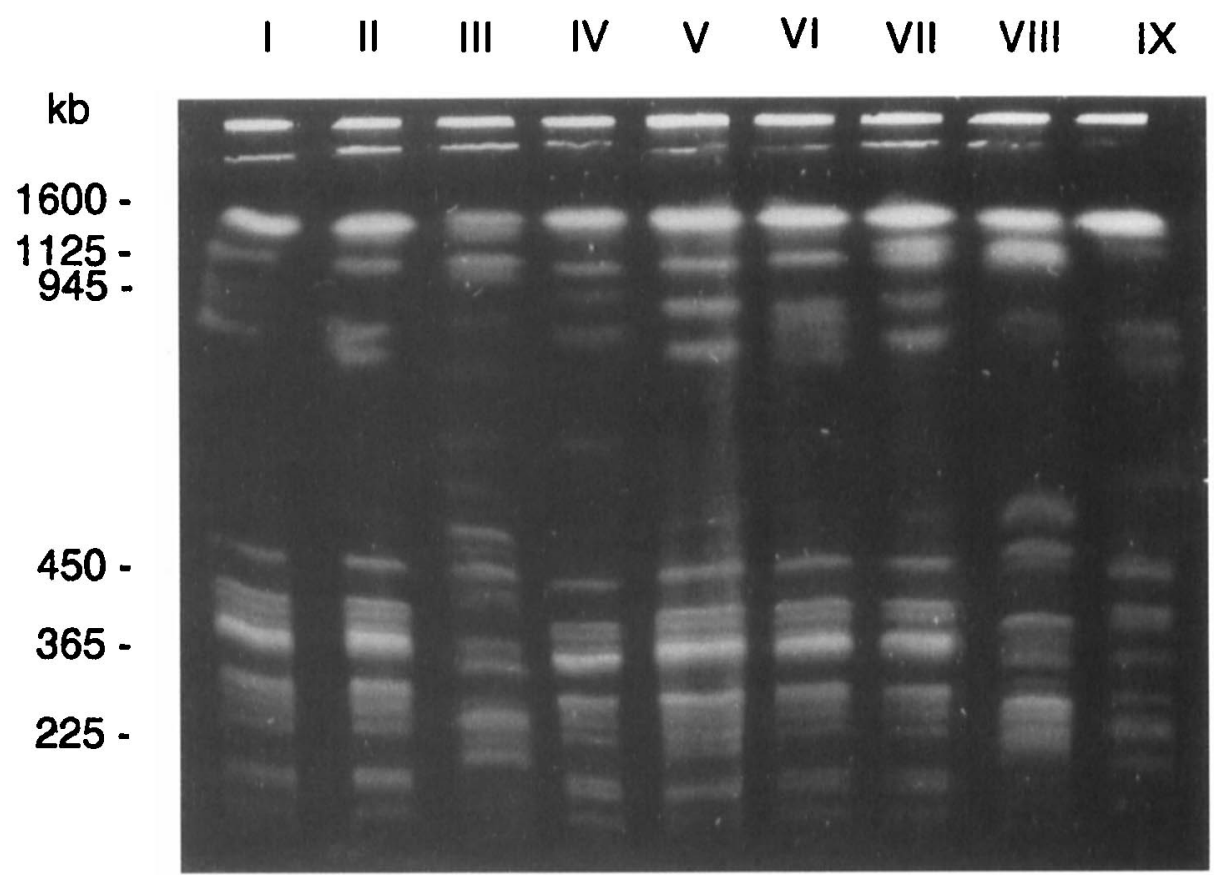

Fig. 3. Representatives of nine proposed Sfi I MEF classes obtained with the 46 isolates of C. parapsilosis. The restriction pattern of only one member for each class is shown. The classes are indicated with a roman number. The most useful sizes $(\mathrm{kb})$, are indicated on the left.

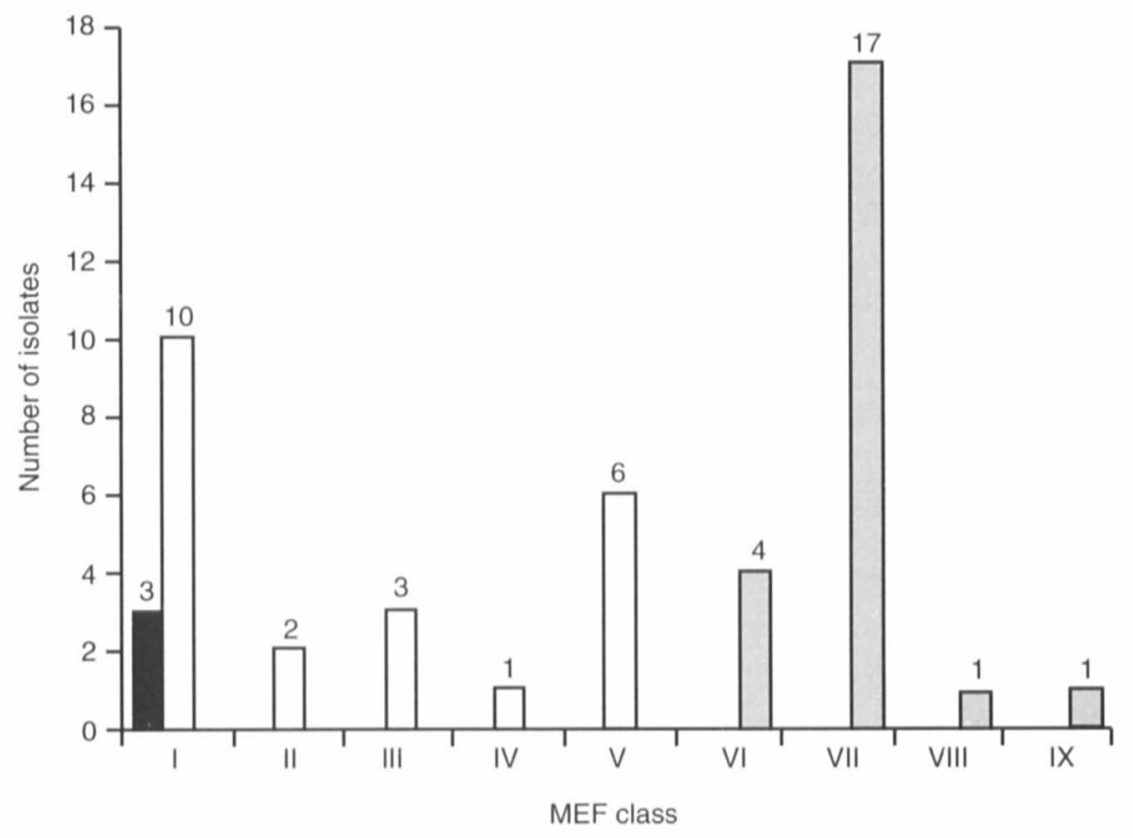

Fig. 4. $S f i$ I MEF classes of the 46 C. parapsilosis isolates for soil

, vaginal samples $(\square)$ and blood cultures

isolate. Furthermore, the five isolates of classes $\mathrm{F}, \mathrm{G}$, $\mathrm{K}$ and $\mathrm{R}$ with an image of the karyotypic pattern were very different from the remaining isolates. Only nine classes were found by $S f i$ I digestion, in contrast with the 18 karyotypic classes, and the two clinical sources (vaginal and blood) were completely separated from each other. Although $S f i$ I generated 20-28 fragments, ranging in size from $50 \mathrm{~kb}$ to $2.2 \mathrm{Mb}$, only the four fragments in the range $1.2-0.75 \mathrm{Mb}$, under these experimental conditions, were useful for typing, and their different size alone allowed the grouping of six out of nine classes. The other three classes (III, VIII and IX) showed many more $S f i$ I macrorestriction fragments. The isolates of these classes were the same as those showing a very distinct electrophoretic karyotype or morphotype class [8]. They were also peculiar by RAPD analysis (data not shown). It may be that these isolates are a variety of $C$. parapsilosis. Of particular interest is the fact that the $S f i \mathrm{I}$ restriction-based classes were closely associated with the clinical source of the isolates. All vaginal isolates belonged to classes (I-V) that did not include any 
blood isolates (classes VI-IX). There was only a limited overlap between the three soil isolates and 10 vaginal isolates (class I). Of additional interest is the fact that, of the 23 blood isolates, 17 (74\%) belonged to one class (VII) whereas the vaginal isolates showed a much broader distribution (into five classes).

Branchini et al. [24] grouped their 31 blood isolates into four classes by Bss HII MEF. They also found a major Bss HII class (A) with $23(74 \%)$ isolates of 31 . Similar results were obtained with $S f i$ I enzyme in the present study for the 23 blood isolates, assigned to a total of four classes and with class VI containing 17 isolates, i.e., $74 \%$ of total blood isolates. This suggests that the blood isolates may be genetically more homogeneous than the vaginal strains. However, no additional comparisons between these data and those of Branchini et al. [24] are possible because 20 vaginal and three soil isolates were also included in the analysis, whereas no isolates from such sources were studied by Branchini et al. [24]. Morever, our analysis was based on the use of $S f i$ I endonuclease whereas a different restriction endonuclease was used by Branchini et al. [24]. Overall, the approach described here seems to give more comprehensive coverage of the various DNA biotype characteristics of C. parapsilosis from different clinical sources.

Further studies are in progress to define the virulence properties of the different isolates of $C$. parapsilosis by both mucosal and systemic models of experimental infections, so as to assess possible correlations between the different Sfi I MEF classes, source of isolation and pathogenicity.

This work was supported by the Progetto Finalizzato CNR (Italy) 'Biotecnologia e Biostrumententazione' and Progetto Nazionale AIDS (Contract $\mathrm{N}^{\circ} 820 / \mathrm{U}$ ). We are grateful to A. Cassone MD (Director of Laboratory of Bacteriology and Medical Micology Unit, Istituto Superiore di Sanità, Roma), who critically read the manuscript and provided constructive suggestions, and to Professor P. Martino who supplied the blood isolates.

\section{References}

1. Meunier-Carpentier F, Kiehn TE, Armstrong D. Fungemia in the immunocompromised host. Changing patterns, antigenemia, high mortality. Am J Med 1981; 71: 363-370.

2. Komshian SV, Uwaydah AK, Sobel JD, Crane LR. Fungemia caused by Candida species and Torulopsis glabrata in the hospitalized patient: frequency, characteristics, and evaluation of factors influencing outcome. Rev Infect Dis 1989; 11: 379-390.

3. Weems JJ. Candida parapsilosis: epidemiology, pathogenicity, clinical manifestations, and antimicrobial susceptibility. Clin Infect Dis 1992; 14: 756-766.

4. Plouffe JF, Brown DG, Silva JJ, Eck T, Stricof RL, Fekety FR. Nosocomial outbreak of Candida parapsilosis fungemia related to intravenous infusions. Arch Intern Med 1977; 137: 16861689.

5. Weems JJ, Chamberland ME, Ward J, Willy M, Padhye AA, Solomon SL. Candida parapsilosis fungemia associated with parenteral nutrition and contaminated blood pressure transducers. $J$ Clin Microbiol 1987; 25: 1029-1032.
6. De Bernardis F, Lorenzini R, Verticchio R, Agatensi L, Cassone A. Isolation, acid proteinase secretion, and experimental pathogenicity of Candida parapsilosis from outpatients with vaginitis. J Clin Microbiol 1989; 27: 2598-2603.

7. De Bernardis F, Morelli L, Ceddia T, Lorenzini R, Cassone A. Experimental pathogenicity and acid proteinase secretion of vaginal isolates of Candida parapsilosis. J Med Vet Mycol 1990; 28: $125-137$.

8. Cassone A, De Bernardis F, Pontieri E et al. Biotype diversity of Candida parapsilosis and its relationship to the clinical source and experimental pathogenicity. J Infect Disease 1995; 171: $967-975$.

9. Smith RA, Hitchcock CA, Evans EGV, Lacey CJN, Adams DJ. The identification of Candida albicans strains by restriction fragment length polymorphism analysis of DNA. $J$ Med Vet Mycol 1989; 27: 431-434.

10. Wills JW, Lasker BA, Sirotkin K, Riggsby WS. Repetitive DNA of Candida albicans: nuclear and mitochondrial components. $J$ Bacteriol 1984; 157: 918-924.

11. Magee BB, D'Souza TM, Magee PT. Strain and species identification by restriction fragment length polymorphisms in the ribosomal DNA repeat of Candida species. $J$ Bacteriol 1987; 169: 1639-1643.

12. Lasker BA, Page LS, Lott TJ, Kobayashi GS, Medoff G. Characterization of CARE-1: Candida albicans repetitive element-1. Gene 1991; 102: 45-50.

13. Chen J-Y, Fonzi WA. A temperature-regulated retrotransposonlike element from Candida albicans. J Bacteriol 1992; 174 5624-5632.

14. Iwaguchi S-I, Homma M, Chibana H, Tanaka K. Isolation and characterization of a repeated sequence (RPS1) of Candida albicans. J Gen Microbiol 1992; 138: 1893-1900.

15. Merz WG, Connelly C, Hieter P. Variation of electrophoretic karyotypes among clinical isolates of Candida albicans. $J$ Clin Microbiol 1988; 26: 842-845.

16. Lasker BA, Carle GF, Kobayashi GS, Medoff G. Comparison of the separation of Candida albicans chromosome-sized DNA by pulsed-field gel electrophoresis technique. Nucleic Acids Res 1989; 17: 3783-3793.

17. Rustchenco-Bulgac EP. Variation of Candida albicans electrophoretic karyotypes. J Bacteriol 1991; 173: 6586-6596.

18. Vazquez JA, Beckley A, Sobel JD, Zervos MJ. Comparison of restriction enzyme analysis and pulsed field gradient gel electrophoresis typing systems for Candida albicans. $J$ Clin Microbiol 1991; 29: 962-967.

19. Mahrous M, Lott TJ, Meyer SA, Sawant AD, Ahearn DG. Electrophoretic karyotyping of typical and atypical Candida albicans. J Clin Microbiol 1990; 28: 876-881.

20. Vollrath D, Davis RW. Resolution of DNA molecules greater than megabases by contour-clamped homogeneous electric fields. Nucleic Acids Res 1987; 15: 7865-7876.

21. Thrash-Bingham C, Gorman JA. DNA translocations contribute to chromosome length polymorphisms in Candida albicans. Curr Gen 1992; 22: 93-100.

22. Carruba G, Pontieri E, De Bernardis F, Martino P, Cassone A. DNA fingerprinting and electrophoretic karyotype of environmental and clinical isolates of Candida parapsilosis. $J$ Clin Microbiol 1991; 29: 916-922.

23. Lott TJ, Kuykendall RJ, Welbel SF, Pramanik A, Lasker BA. Genomic heterogeneity in the yeast Candida parapsilosis. Curr Gen 1993; 23: 463-467.

24. Branchini ML, Pfaller MA, Rhine-Chalberg J, Frampong T, Isenberg HD. Genotypic variation and slime production among blood and catheter isolates of Candida parapsilosis. J Clin Microbiol 1994; 32: 452-456.

25. Sambrook J, Fritsch EF, Maniatis T. Molecular cloning: a laboratory manual, 2nd edn. Cold Spring Harbor, NY, Cold Spring Harbor Laboratory Press. 1989.

26. Carruba G, Pontieri E, Gennarelli M, Gregori L, Ceddia T, De Bernardis F. Biotipizzazione molecolare di un patogeno emergente, Candida parapsilosis con particolare riferimento all'uso di varie tecniche di elettroforesi pulsata nell'analisi del cariotipo. Min Biotecnol 1992; 4: 20-25.

27. Scherer S, Stevens DA. Application of DNA typing methods to epidemiology and taxonomy of Candida species. $J$ Clin Microbiol 1987; 25: 675-679. 